\title{
PERANCANGAN SISTEM E-LEARNING BERBASIS WEB PADA SMP N 2 BUSALANGGA
}

\author{
Jimi Asmara \\ STIKOM Uyelindo Kupang, Nusa Tenggara Timur 85111 \\ jimmyasmara26@gmail.com
}

\begin{abstract}
Abstrak
Perkembangan Teknologi saat ini berkembang begitu pesat, hampir semua aspek kehidupan manusia semua menggunakan teknologi. Kebutuhan akan satu konsep dan mekanisme belajar mengajar (pendidikan) berbasis TI semakin lebih maju yang kemudian dikenal dengan sebutam E-learning ini membawa pengaruh terjadinya transformasi pendidikan konvensional ke dalam bentuk digital, baik secara isi (contens) dan sistemnya. E-learning merupakan model pembelajaran yang memanfaatkan fasilitas teknologi informasi dan komunikasi. Dengan teknologi informasi ini dapat berperan sebagai yang menyediakan informasi antara siswa dan pelajar, sumber belajar dan sarana untuk mengefektifkan evaluasi pembelajaran. SMP Negeri 2 Busalangga sebagai salah satu sekolah negeri yang proses kegiatan belajar mengajarnya masih menggunakan cara konvensional. Untuk mendidik para siswa atau anak didiknya dalam menghadapi ujian nasional maka para guru atau pihak sekolah selalu mengadakan bimbingan belajar atau try out, pra ujian nasional di luar jam sekolah. Metode yang digunakan pada penelitian ini adalah metode kualitatif, Hasil yang didapat berupa rancangan media website e-learning yang akan dapat digunakan untuk kegiatan belajar mengajar berbasis IT
\end{abstract}

Kata Kunci : e-learning, informasi, sekolah, website

\section{PENDAHULUAN}

Perkembangan Teknologi saat ini berkembang begitu pesat, hampir semua aspek kehidupan manusia semua menggunakan teknologi. Kebutuhan akan satu konsep dan mekanisme belajar mengajar (pendidikan) berbasis TI semakin lebih maju yang kemudian terkenal dengan sebutam E-learning ini membawa pengaruh terjadinya transformasi pendidikan konvensional ke dalam bentuk digital, baik secara isi (contens) dan sistemnya. Saat ini konsep E-learning sudah banyak diterima oleh masyarakat dunia, terbukti dengan maraknya implementasi di lembaga pendidikan oleh masyarakat, terbukti dengan maraknya E-learning di lembaga pendidikan (sekolah, training dan universitas) maupun industri (Cisco System, IBM, HP, Oracle ).
E-learning merupakan model pembelajaran yang memanfaatkan fasilitas teknologi informasi dan komunikasi. Dengan teknologi informasi ini dapat berperan sebagai yang menyediakan antara siswa dan pelajar, sumber belajar dan sarana untuk mengefektifkan evaluasi pembelajaran. SMP Negeri 2 Rote Busalangga sebagai salah satu sekolah negeri yang sudah menggunakan ujian nasional berbasis computer (online), sehingga sekolah ini berusaha menjaga kualitas peserta didiknya.

Dengan adanya Program bimbingan belajar dan Try Out yang dilaksanakan pada sekolah SMP Negeri 2 Rote Busalangga selama ini menggunakan metode pembelajaran konvensional yang pelaksanaannya membutuhkan waktu 
kurang lebih dari 2 jam setiap 1 mata pelajaran. Sehingga siswa tidak banyak waktu untuk mengerjakan latihan soal dan mendalami materi yang sudah ada. Hal ini mengindikasikan bahwa bimbingan belajar atau Try Out yang menggunakan system konvensional masih memiliki keterbatasan waktu yang dimiliki oleh siswa membuat siswa tidak maksimal untuk belajar dan mengerjakan latihan soal yang diberikan sehingga nilai yang dihasilkan tidak sesuai dengan standar kelulusan yang diharapkan. Maka diperlukan metode tambahan yaitu system E-learning berbasis online yang mana system ini akan membantu siwa untuk belajar dan mengerjakan latihan soal untuk menghadapi persiapan ujian nasional dengan maksimal sehingga menghasilkan nilai yang diharapkan oleh guru.

Yang menjadi rumusan masalah pada penelitian ini adalah : Bagaimana merancang sebuah sistem E-learning ditinjau dari SDM, materi dan bahan ajar dan infrastruktur untuk membangun sistem pembelajaran materi dan ujian Try Out bagi SMP Negeri 2 Busalangga?

Penelitian terdahulu yang pernah dilakukan oleh Dewi dengan judul perangan aplikasi e-learning berbasis web pada SMA/SMK Dharma Bakti Medan, pada penelitian ini menekan pada pengembangan sistem untuk membantu pihak guru di SMA/SMK dharma bakti medan [1]. Penelitian yang dilakukan oleh Kosasih dengan judul perancangan elearning untuk meningkatkan motivasi siswa dan guru dengan adanya penelitian ini membantu para guru dalam proses belajar mengajar secara daring [2].

\section{Website.}

Website merupakan kumpulan dari halaman-halaman yang berhubungan denganfile-file lain yang saling terkait. Dalam sebuah website terdapat satu halamanyang dikenal dengan sebutan homepage. Homepage adalah sebuah halaman yang pertama kali dilihat ketika seseorang mengunjungi sebuah website [3]

\section{PHP.}

PHP (Hypertext Preprocessor), merupakan bahasa pemrograman scrip yang ditanam dalam HTML. pada sisi server yang memperbolehkan programmer menyisipkan perintah - perintah perangkat lunak web server (apache, IIS, atau apapun) akan dieksekusi sebelum perintah itu dikirim oleh halaman ke browser yang merequest-nya [3].

\section{Pengertian E-learning .}

E-learning adalah salah satu bentuk pendidikan yang menggabungkan motivasi, komunikasi, efisiensi dan teknologi. Sering kali proses pembelajaran mengalami keterbatasan waktu dan jarak tetapi tidak dengan e-learning yang bisa diakses diamana saja [3].

\section{Manfaat E-learning.}

Pada pembelajaran e-learning pelajar secara invidu pada waktu tertentu dan bertanggungjawab untuk pelajarannya sendiri. E-learning sendiri menyediakan perangkat yang dapat memperkaya nilai belajar konvensional. Kapasitas siswa sangat bervariasi tergantung pada bentuk isi dan penyampaiannya, semakin baik keselarasan antar konten dan alat penyampaian belajar maka akan memberi hasil yang baik. [3]

\section{METODE PENELITIAN}

Kebutuhan sistem. Berikut adalah penjelasan berbagai hal mengenai software yang akan digunakan dalam merancangan 
sistem e-learning pada SMP N 2

Busalangga. MySQL adalah database yang menghubungkan script PHP menggunakan perintah query dan escaps character yang sama dengan PHP. MySQL mempunyai tampilan client yang mempermudah dalam mengakses database dengan kata sandi untuk mengizinkan proses yang bias dilakukan [4].

\section{Kebutuhan Perangkat Keras dan Perangkat lunak}

Laptop dengan prosesor Intel(R) Celeron(R) CPU N3060 @ 1.60GHZ ,RAM 4 GB DDR3, Harddisk 500 GB. Microsoft Windows 10 Home Single language XAMPP Editor Web Notepad++, Sublime Text Web Browser, ms visio

Berikut flowchart rancangan sistem elearning pada SMP N 2 Busalangga.

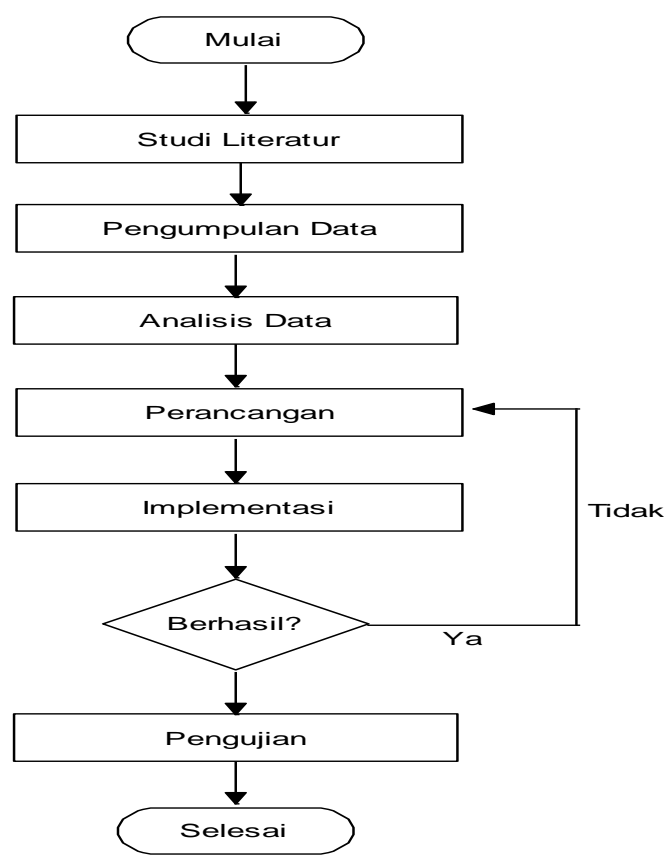

Gambar 1. Diagram alur proses

Berdasarkan alur flowchart penelitian pada gambar 1, maka dapat dijelaskan sebagai berikut:

a. Studi Literatur: penelitian dimulai dengan studi literatur yaitu dilakukan dengan mencari referensi-referensi dari berbagai jurnal, buku, dan skripsi yang ada untuk memperkaya sumber penelitian ini.

b. Pengumpulan Data: pengumpulan data dilakukan dengan cara melakukan wawancara dengan Pegawai dan melakukan observasi langsung ke tempat penelitian yaitu di SMP Negrei 2 Busalangga,

c. Analisis Data: analisis data yaitu dengan cara menganalisa data apa yang akan dipakai dalam penelitian ini.

d. Perancangan: tahap ini merupakan tahap merancang sebuah perancangan yang sesuai dengan data yang telah dikumpulkan, dianalisa dan siap dilakukan perancangan.

e. Implementasi: pada tahap ini dilakukan implementasi atau penerapan program yang telah dibangun ke lapangan untuk digunakan sebagaimana mestinya.

f. Pengujian: pada tahap ini dilakukan pengujian dari aplikasi yang telah dibangun dan dirancang apakah sudah benar dan sesuai dengan hasil yang diharapkan, jika aplikasi tersebut sudah benar dan sesuai dengan hasil yang diharapkan maka aplikasi tersebut siap diimplementasikan dan jika aplikasi tersebut masih belum benar dan belum sesuai dengan hasil yang diharapkan maka akan kembali ke tahap perancangan untuk perbaikan.

g. Selesai.

\section{HASIL DAN PEMBAHASAN}

Dalam prakteknya e-learning memerlukan bantuan teknologi karena itu dikenal istilah computer based learning (CBL) yaitu pembelajaran yang sepenuhnya menggunakan komputer dan computer assisted learning yaitu pembelajaran yang menggunakan alat bantu utama komputer. 


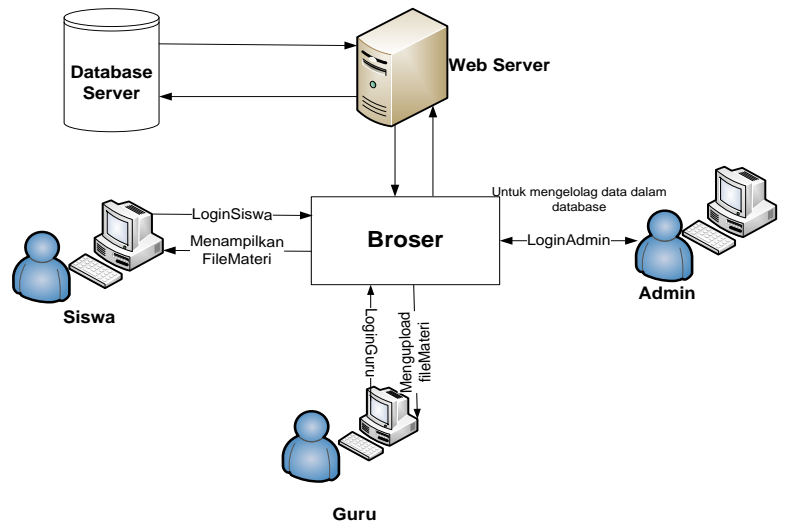

Gambar 2. Rancangan Arsitektur Sistem E-learning

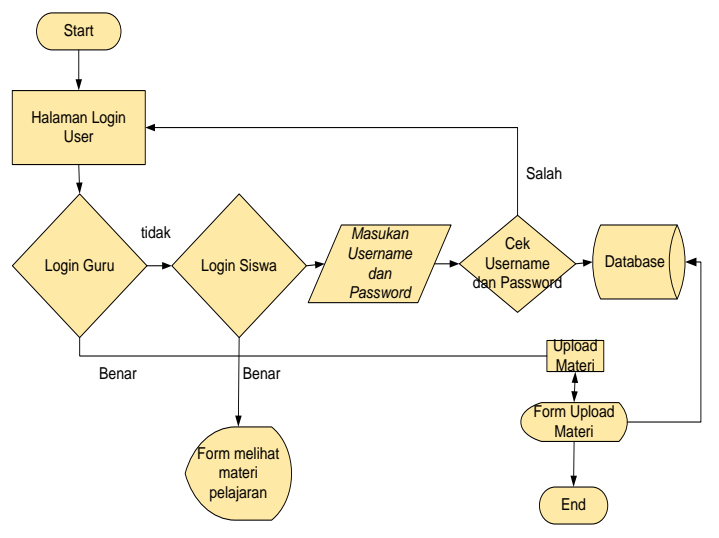

Gambar 3. Rancangan Sistem flowchart Login Guru dan Siswa Aplikasi E-learning

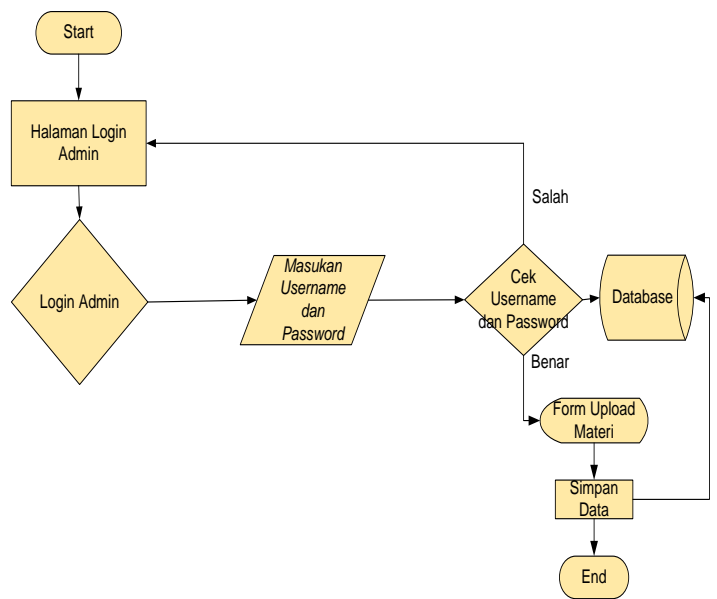

Gambar 4. Rancangan Sistem flowchart Login Admin Aplikasi E-learning

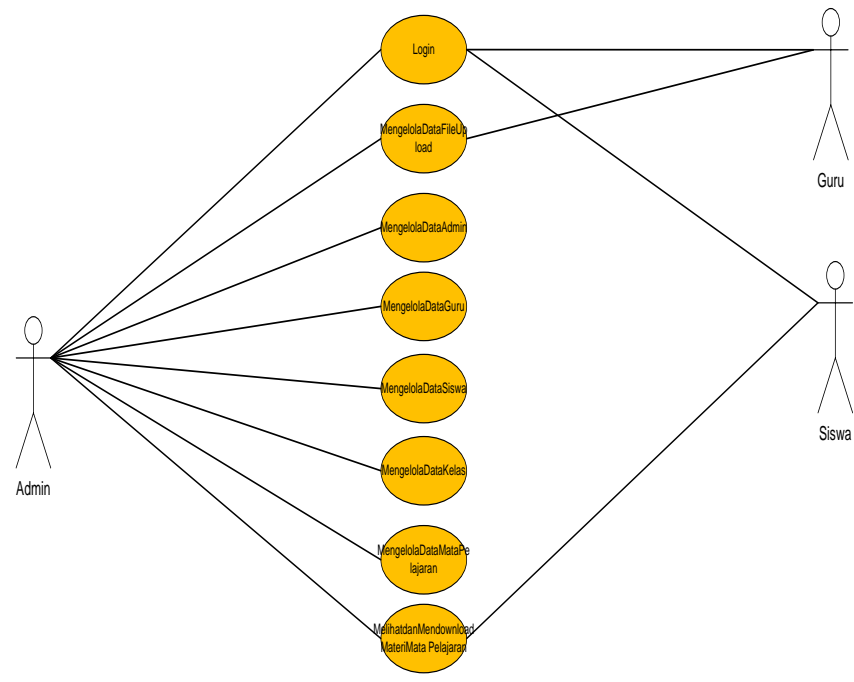

Gambar 5. Use Case Diagram

Pada gambar diatas dijelaskan bahwa pada aplikasi ini terdapat aktor yang berinterkasi dengan system yaitu aktor pengguna (User) dan aktor pengelola (Admin). Masing masing actor memiliki interaksi dan tugas yang berbeda-beda dimana aktor (User) hanya bisa melihat, mendowload dan mengupload data materi mata pelajarantanpa bisa mengelola data, sedangkan aktor pengelola (Admin) bisa dapat melihat dan mengelola data yang terdapat di dalam database [5].

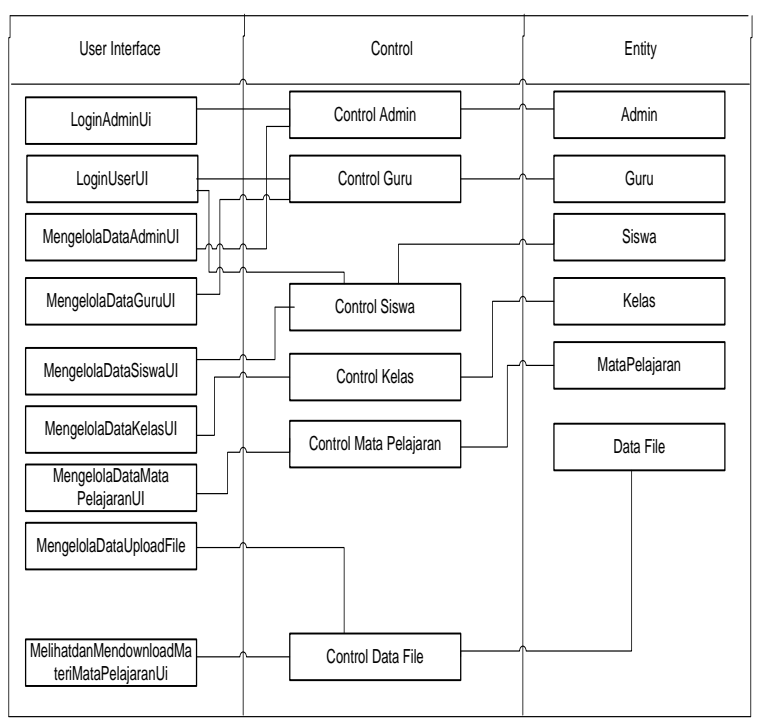

Gambar 6. Rancangan Arsitektur layer 


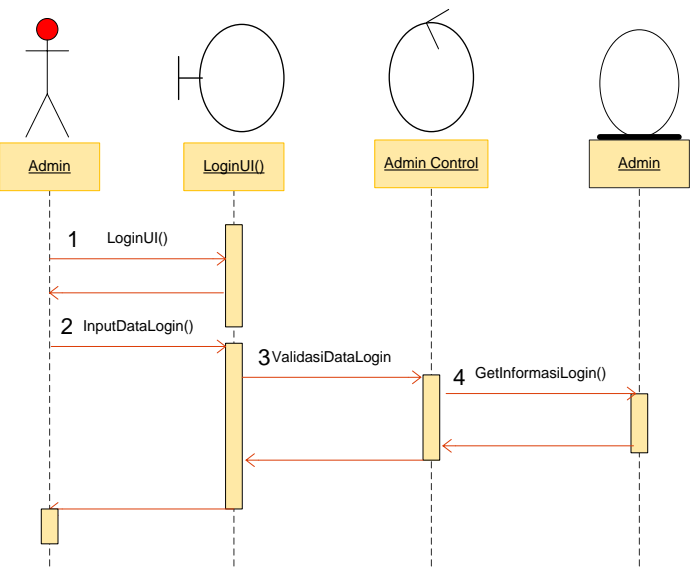

Gambar 7. Rancangan Sequence diagram Login (admin).

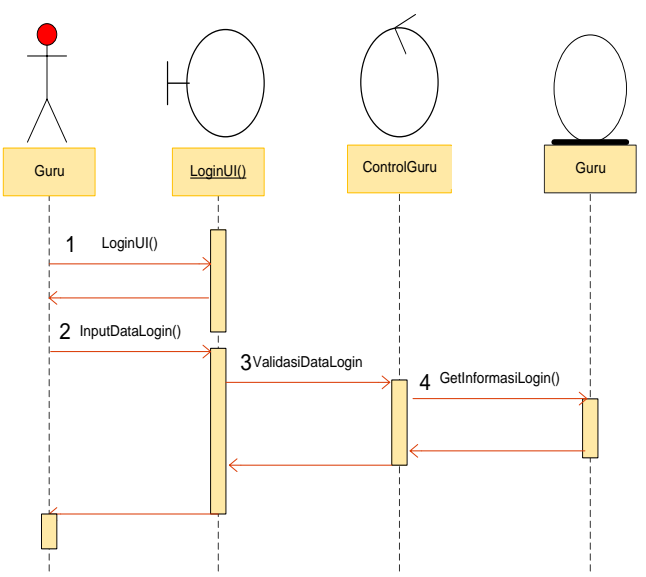

Gambar 8. Rancangan Sequence diagram login guru

Class diagram merupakan suatu diagram yang memperlihatkan atau menampilkan struktur dari sebuah sistem, sistem tersebut akan menampilkan sistem kelas, atribut, dan hubungan antara kelas ketika suatu sistem telah selesai membuat diagram. Gambar class diagram dapat dilihat pada gambar disamping [5].

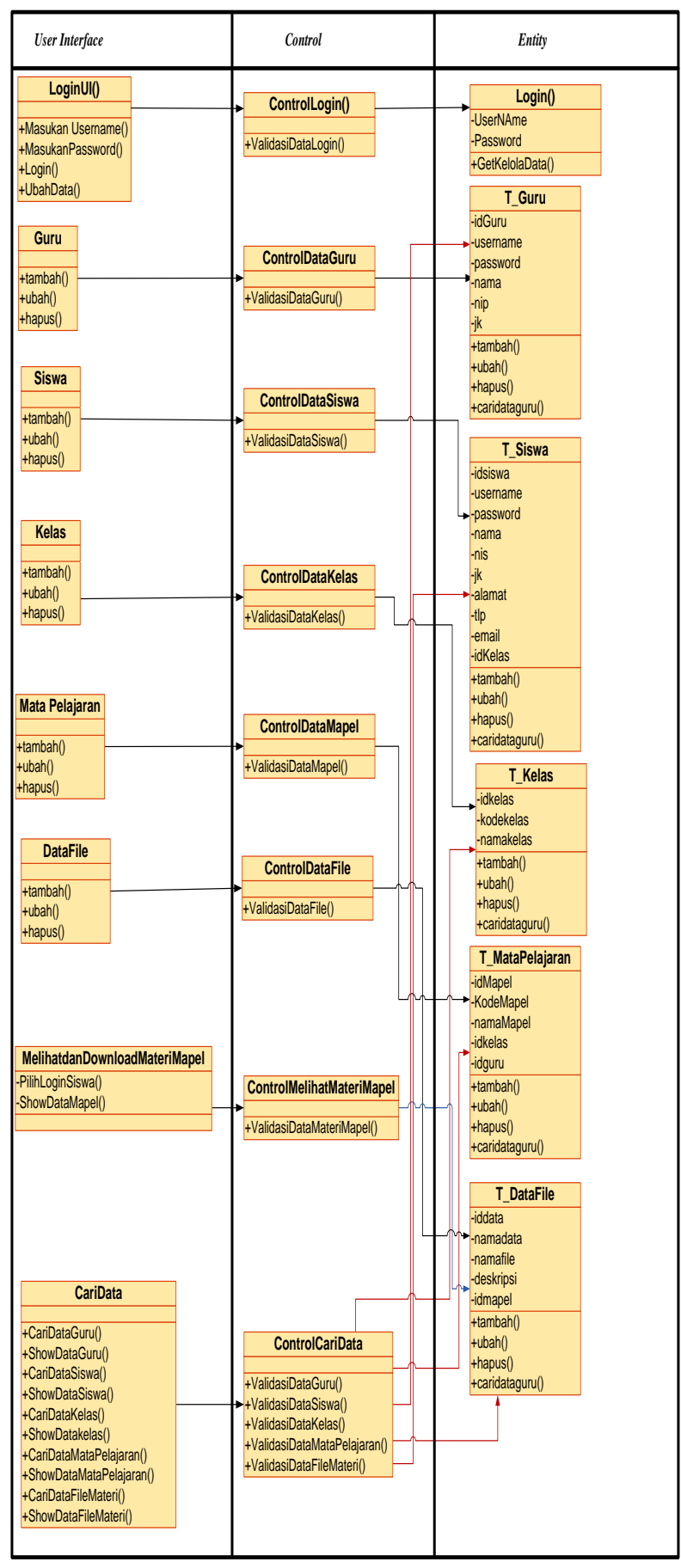

Gambar 9. Rancangan Class diagram sistem e-learning

\section{Perancangan Antarmuka}

Perancangan antarmuka (dialog layar terminal interface) merupakan rancang bangun dari percakapan antara pemakai sistem dengan komputer [5]. Percakapan tersebut terdiri dari proses memasukkan data ke dalam input, menampilkan keluaran (output) informasi, atau dapat keduanya. 
Tampilannya secara lengkap dapat dilihat pada gambar berikut ini.

\section{a. Rancangan Login User}

Login user digunakan guru untuk masuk mengupload materi pelajaran, login user juga digunakan siswa untuk melihat materi setiap mata pelajaran.

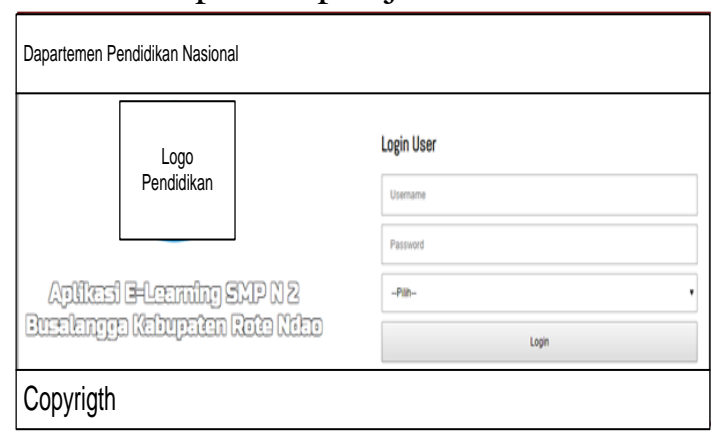

Gambar 10 Rancangan login user

b. Rancangan Login Admin

Login admin merupakan pintu yang digunakan untuk masuk mengelola data di dalam sistem.

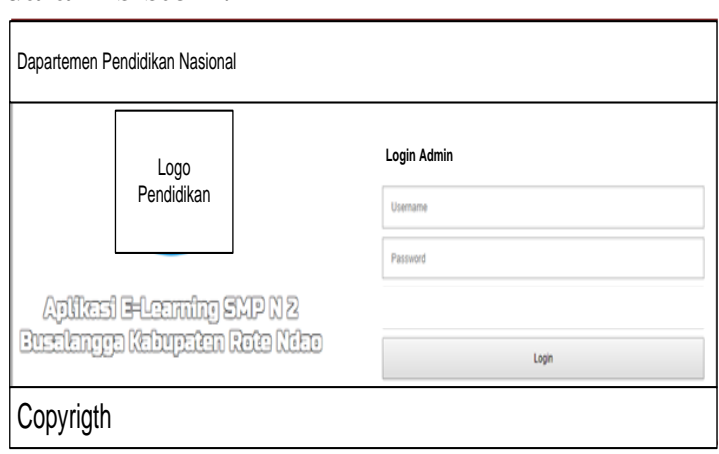

Gambar 11 Rancangan login admin

c. Rancangan Form Admin Panel

Rancangan tampilan awal form untuk mengelola data.

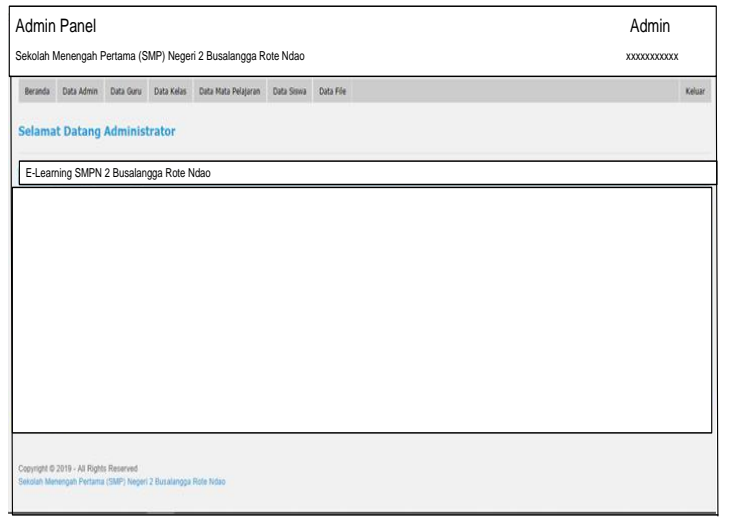

Gambar 12. Rancangan Tampilan Form Admin Panel

d. Rancangan Form tambah data admin

Form tambah data admin merupakan form yang akan digunakan admin untuk mengelola username dan password admin sistem

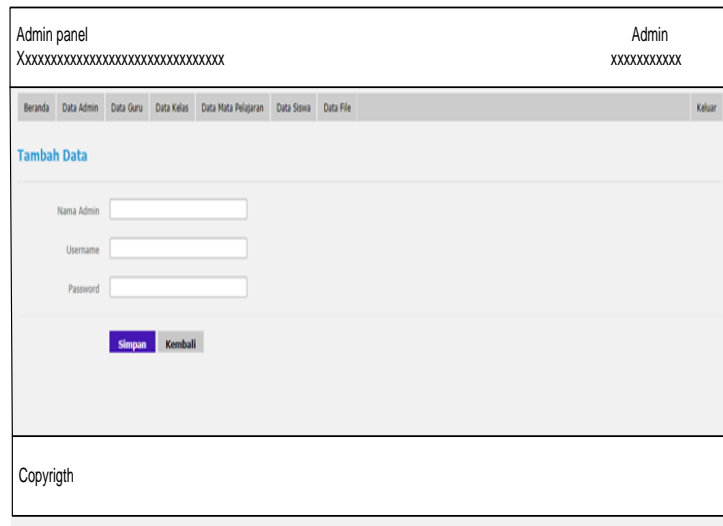

Gambar 13. Rancangan Form tambah data admin

e. Rancangan formTampilan data admin form ini akan menampilkan data admin pengelola sistem.

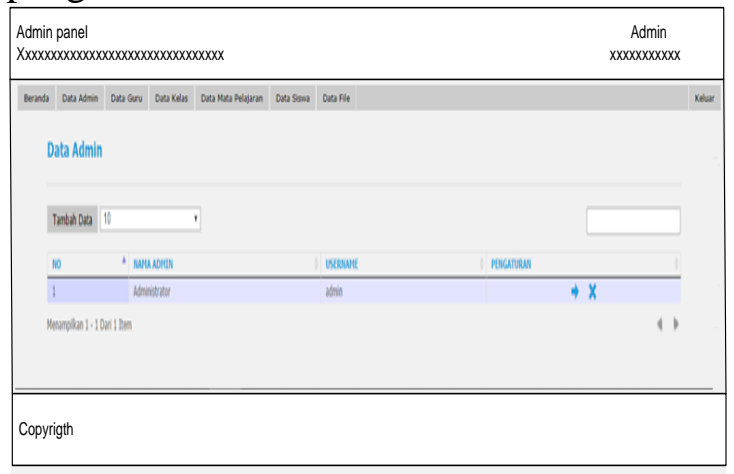

Gambar 14. Rancangan Tampilan data admin 
Jurnal Pendidikan Teknologi Informasi (JUKANTI) Volume (3) No (1) April 2020 e-ISSN : 2621-1467

f. Rancangan Tambah data guru Form ini digunakan admin untuk mengelola atau menambahkan data guru.

\begin{tabular}{|c|c|}
\hline $\begin{array}{l}\text { Admin panel } \\
\text { Xxxxxxxxxxxxxxxxxxxxxxxxxxxxxxxxxx }\end{array}$ & $\underset{x x x x x x x x x x x x}{\text { Admin }}$ \\
\hline 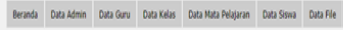 & nes \\
\hline \multicolumn{2}{|l|}{ Tambah Data } \\
\hline $\operatorname{man}$ an $\square$ & \\
\hline Nomer masteregoma $\square$ & \\
\hline Jims xdaminn & \\
\hline vesement $\square$ & \\
\hline$\square$ & \\
\hline Simson Kemball & \\
\hline Copyrigth & \\
\hline
\end{tabular}

Gambar 15. Rancangan Tamba data guru

g. Rancangan form Tampilan data guru ini akan menampilkan data guru yang telah diinput

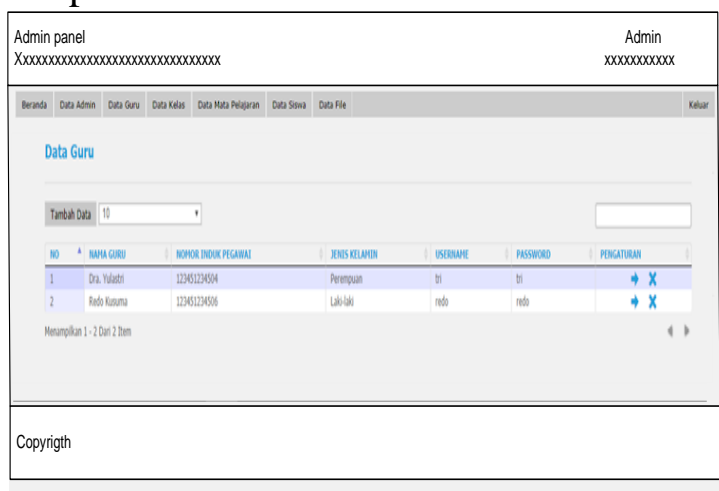

Gambar 16 Rancangan data guru

h. Rancangan Form tambah data kelas

Form ini digunakan admin untuk menambah data kelas.

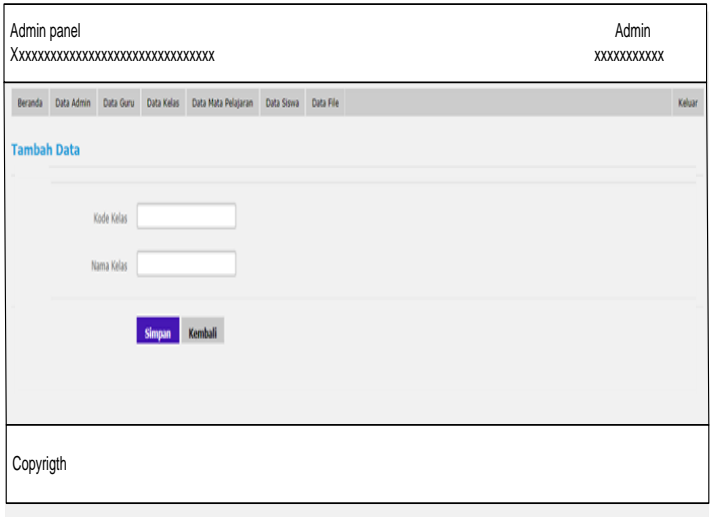

Gambar 17. Rancangan Form tambah data kelas

i. Rancangan form Tampilan data kelas yang telah diinput

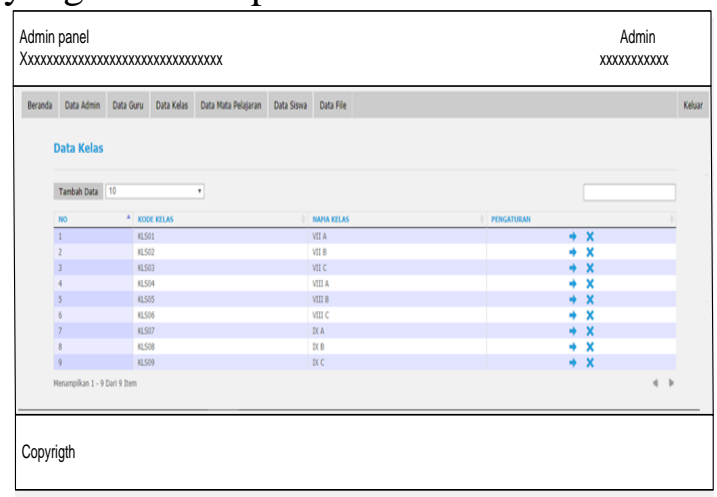

Gambar 18. Rancangan Tampilan data kelas

j. Rancangan Form tambah mata pelajaran Form ini digunakan admin untuk menginput data mata pelajaran.

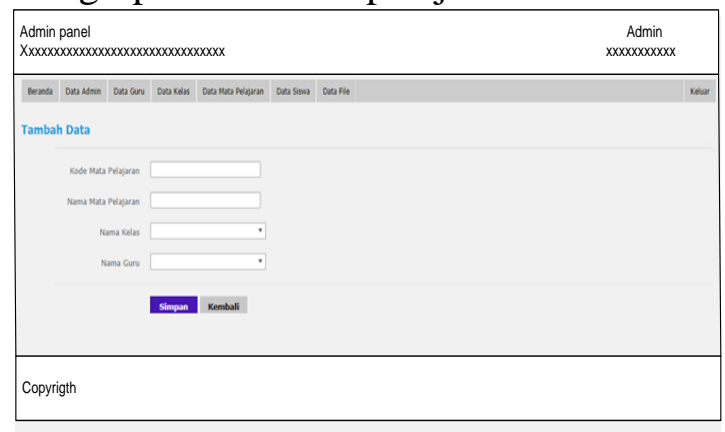

Gambar 19. Rancangan Form tambah mata pelajaran 
k. Rancangan Form tampilan data mata pelajaran ini menampilkan data matapelajaran yang telah diinput

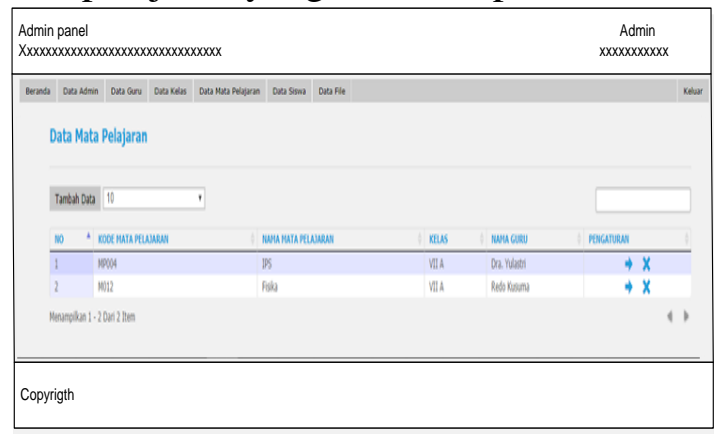

Gambar 20. Rancangan Form tampilan data mata pelajaran

1. Rancangan Form tambah data siswa Form ini digunakan admin untuk menginput data siswa.

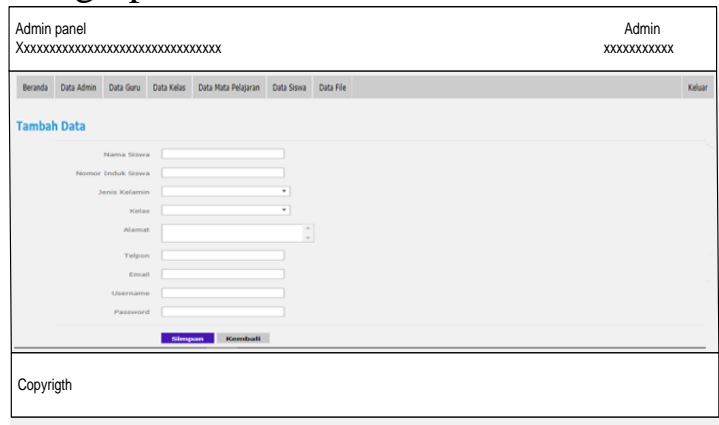

Gambar 21. Rancangan Form tambah data siswa

k. Rancangan Form tampilan data siswa menampilkan data siswa yang telah diinput

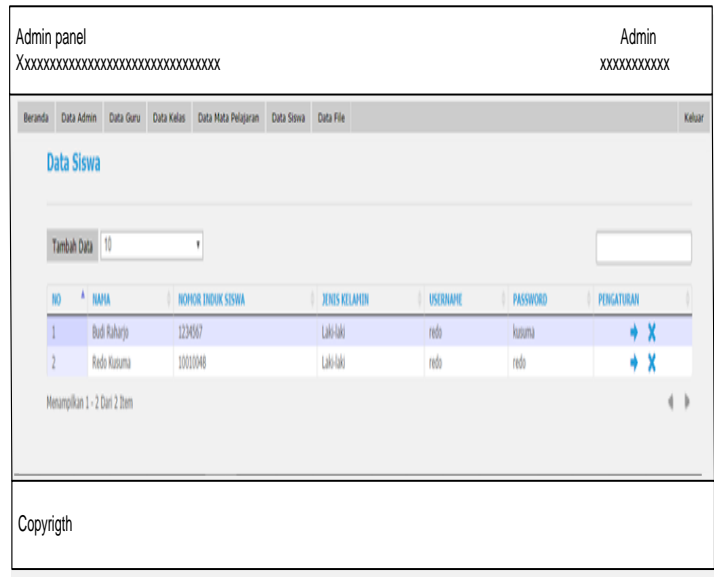

Gambar 22. Rancangan Form tampilan data siswa
1. Rancangan Form tambah data file materi Form ini digunakan oleh admin untuk menginput data file materi, form ini juga bisa digunakan guru untuk mengupload materi.

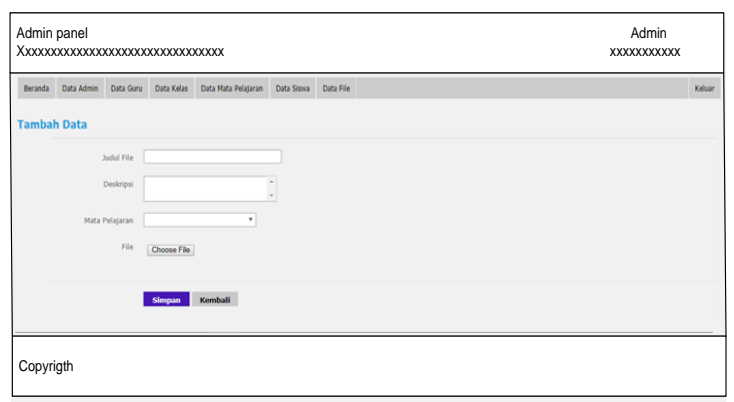

Gambar 23. Rancangan Form tambah data file materi

m. Rancangan Form tampilan data file materi yang sudah diinput

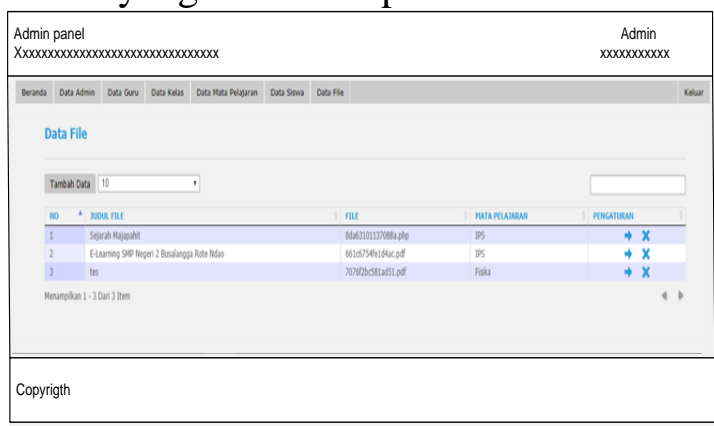

Gambar 24.Rancangan Form tampilan data file materi yang sudah diinput

\section{KESIMPULAN}

Rancangan Aplikasi ini nantinya akan mempermudah guru dan siswa untuk kegiatan belajar mengajar, latihan soal dan dapat mengatasi kendala kegiatan proses belajar mengajar dan implementasi $e$ learning di SMP Negeri 2 Busalangga. Guru juga dapat login kesistem untuk menguplod berita, materi pembelajan,artikel, soal-soal latihan. Sedangkan siswa dapat melihat berita,artikel pengumuman dan download materi pelajaran. 


\section{SARAN}

Penelitian yang dilakukan masih ada beberapa kekurangan, sehingga penulis memberikan saran :

a. Perlu adanya perbaikan infrastruktur jaringan internet khususnya di Kabupaten Rote Ndao untuk penerapan e-learning.

b. Perlu adanya bimbingan penggunaan aplikasi e-learning pada guru

c. Perlunya pengembangan sistem dengan media interaktif yang lebih menarik untuk proses pembelajaran pada aplikasi.

\section{DAFTAR PUSTAKA}

[1] Kosasi, Sandi, "Perancangan Elearning untuk meningkatkan motivasi belajar guru dan siswa" prosiding seminar nasional pendidikan teknik informatika, 2015.

[2] Dewi, Rofiqoh “perancangan aplikasi e-learning berbasis website pada SMA/SMK Dharma Bakti Medan" konferensi nasional sistem dan informatika, 2015.

[3]. Turban, Effraim "Pengertian ELearning", Penerbit Andi Yogyakarta, 2006.

[4] Sianipan,R.H, "Membangun Web dengan PHP \& MySQL", untuk pemula dan programe, penerbit Informatika, 2007

[5] H.M, Jogiyanto "Analisis dan Desain Sisem", penerbit Andi, Yogyakarta, 2002. 